\title{
Chemical Composition and Organoleptic Properties of Meatballs Based on Afkir Laying Chicken
}

\author{
Ni Made Yudiastari ${ }^{1^{*}}$, Yan Tonga ${ }^{2}$, Ni Ketut Etty Suwitari ${ }^{3}$, I Nyoman Kaca ${ }^{4}$, Luh \\ Suariani $^{5}$, I Gusti Agus Maha Putra Sanjaya ${ }^{6}$ \\ Universitas Warmadewa, Denpasar-Bali, Indonesia \\ \{mdyudiastari@yahoo.com ${ }^{1}$ \}
}

\begin{abstract}
Laying hens are one of the poultry producers that can add value to meat consumption in Indonesia. Laying hens are a type of laying hens where their productivity has decreased, but these chickens can still be used as food to meet the needs of animal protein. Afkir layer chicken meat has low quality because the cutting is done at a relatively old age so that the meat tenderness is lower and is less liked by the community. This research aims to study the chemical characteristics and organoleptic properties at several levels of egg-laying chicken and tapioca flour as an extender in making meatballs. The method used in this study was a completely randomized design (CRD) with 5 (five) treatments and 3 (three) replications, with treatment, R0 for laying hens without tapioca flour, R1 for laying hens without tapioca flour, R1 for laying hens, 5\% for tapioca flour, R2 for for laying hens with $10 \%$ tapioca flour, R3 for laying hens without tapioca flour, R4 for laying hens for $20 \%$ tapioca flour. Afkir layer chicken meatballs with the addition of $15 \%$ tapioca flour had the highest value of chewiness, texture and surface smoothness with each value of 6,$536 ; 6,818$ and 6,729 . The treatment of adding 5\% -20\% tapioca flour fulfilled SNI 01-3818 of 1995 on parameters of moisture content, ash content, fat content and protein content. Afkir layer chicken meatballs with the addition of $15 \%$ tapioca flour had the highest value of chewiness, texture and surface smoothness with each value of 6,$536 ; 6,818$ and 6,729 . The treatment of adding 5\% -20\% tapioca flour fulfilled SNI 01-3818 of 1995 on parameters of moisture content, ash content, fat content and protein content. Afkir layer chicken meatballs with the addition of $15 \%$ tapioca flour had the highest value of chewiness, texture and surface smoothness with each value of 6,536;6,818 and 6,729. The treatment of adding 5\% -20\% tapioca flour fulfilled SNI $01-3818$ of 1995 on parameters of moisture content, ash content, fat content and protein content.
\end{abstract}

Keywords: Afkir layer chicken; meatballs; organoleptic

\section{Introduction}

Meat is one of the animal foods needed for human survival, because it is rich in protein and complete amino acids needed by the body [1]. In order to fulfill and improve community nutrition, namely through consumption of animal protein, it is necessary to do so by utilizing local resources. In order to increase the added value of meat products, it can be pursued by means of techniques and variations in processing that would increase consumer appetite

Bakso is a snack food made from processed meat products that are known and liked by many people. This food material generally uses beef as its raw material, so it is necessary to 
think about the use of meat from other livestock for making meatballs but must still pay attention to the level of consumer preference. The level of consumer preference can be measured using an organoleptic test through the senses. The use of this test includes for the development of new products [2]. According to [3], testing of foodstuffs is not only seen from the chemical aspect, but also from the taste and aroma. Therefore, the organoleptic test needs to be done to find out how far the meatball products that use raw materials other than beef can be liked by consumers. Taste, smell and chewiness are factors that need attention in making meatballs. Consumers generally like meatballs which are compact, elastic, chewy but not hard and not mushy. Taste is an important criterion in assessing a food product that involves a lot of the taste buds, namely the tongue, according to [3], that taste is strongly influenced by chemical compounds, temperature, consistency and interactions with food constituents such as protein, fat, vitamins and many other components. The smell that comes from the meat can be carried over to the processed product. The odor contained in meat is influenced by age, genetics, nationality, environment, food and chemical composition of the meat [4]. Taste is an important criterion in assessing a food product that involves a lot of taste, namely the tongue, according to [3], that taste is strongly influenced by chemical compounds, temperature, consistency and interactions with food constituents such as protein, fat, vitamins and many other components. The smell that comes from the meat can be carried over to the processed product. The odor contained in meat is influenced by age, genetics, nationality, environment, food and chemical composition of the meat [4]. Taste is an important criterion in assessing a food product that involves a lot of the taste buds, namely the tongue, according to [3], that taste is strongly influenced by chemical compounds, temperature, consistency and interactions with food constituents such as protein, fat, vitamins and many other components. The smell that comes from the meat can be carried over to the processed product. The odor contained in meat is influenced by age, genetics, nationality, environment, food and chemical composition of the meat [4]. The smell that comes from the meat can be carried over to the processed product. The odor contained in meat is influenced by age, genetics, nationality, environment, food and chemical composition of the meat [4]. The smell that comes from the meat can be carried over to the processed product. The odor contained in meat is influenced by age, genetics, nationality, environment, food and chemical composition of the meat [4].

The organoleptic test is the result of a physicological reaction in the form of a response or quality impression by a group of people called a panelist. Panelists are a group of people whose job is to assess the nature or quality of materials based on subjective impressions. [2] classified the panelists into six groups, namely: individual tasting panelists, limited tasting panelists, trained panelists, moderately trained panelists and consumer panelists.

Poultry meat has better nutritional value than red meat (beef). Among them, it has short fiber so it is not tough and easy to digest, contains essential amino acids the body needs, has more unsaturated fatty acids and is low in cholesterol, has a distinctive aroma, also contains vitamin B1. In addition, chicken meat is easier to find in the market, high meat production, easy to process and relatively inexpensive when compared to the higher price of beef. This is why chicken is often used in making meatballs. Bakso is a very popular processed meat product and can be found all over Indonesia, from street vendors to large restaurants.

Laying hens are one of the poultry producers that can add value to meat consumption in Indonesia. Laying hens are a type of laying hens where their productivity has decreased, but these chickens can still be used as food to meet the needs of animal protein. Afkir layer chicken meat has low quality because the cutting is done at a relatively old age so that the meat tenderness is lower and is less liked by the community [5]. The increase in the population of laying hens was followed by an increase in the number of chickens that were 
rejected. Therefore, it is necessary to use rejected laying hens to increase their economic value and increase the supply of poultry meat. One of the things that has been done a lot is by processing it into betutu and chicken meatballs.

Tapioca flour is one of the supporting ingredients in making meatballs. Tapioca flour (88.01) has a higher starch content than cornstarch $(54.1 \mathrm{~g})$, rice flour $(-25 \%$ starch $)$ and glutinous rice flour (17-25\% starch). Starch plays an important role in determining the texture of food, where a mixture of starch granules and water when heated will form a gel. Starch that turns into gel is irreversible where the starch molecules stick together to form a lump so that its viscosity increases [6].

To prove the composition of tapioca flour, how to produce better quality of meatballs, a variation of the composition of tapioca flour was carried out in order to produce a better texture of the meatballs. Therefore, the authors are interested in researching the processing of egg-laying hens, which until now has not been used as a base for making meatballs.

\section{Method}

The research was conducted at the Basic Science Laboratory, Faculty of Agriculture, Warmadewa University. The research will be carried out from May 2020 to July 2020.

The research was conducted using a completely randomized design (CRD) method with 5 (five) treatments and 3 (three) replications. The treatments were meat without tapioca flour (R0), 5\% tapioca flour (R1) for egg laying, 10\% tapioca flour (R2), 15\% tapioca flour (R3), and $20 \%$ tapioca flour (R4) for laying hens. Organoleptic testing (color, taste, smell and elasticity) with a score of 1 to 5, involving 20 semi-trained panelists. The descriptions for each are: tenderness score 1 (not soft) to 5 very soft), smell score 1 (very fishy) to 5 (not fishy), taste score 1 (not good) to 5 (very good) and color (pale red) a score of 1 to (very red) a score of 5 .

The materials used in this study were red chicken meat, tapioca flour, pepper, garlic, fine salt, ice cubes, egg white and green onions. The tools used in this study were knives, cutting boards, scales, basins, meat grinders, stovetops and trays.

The parameters observed were organoleptic testing using a hedonic scale, moisture content, protein content, fat content, carbohydrate content, and ash content.

The data obtained from the research results were analyzed for variance, if there were significantly different results $(\mathrm{P}<0.05)$ between treatments, Duncan's multiple distance test was carried out.

\section{Results and Discussion}

Meatballs according to treatment were observed according to research parameters, namely subjective and objective. Subjectively, the organoleptic test was carried out using the hedonic scale (Table 1), while subjectively the water content, protein content, fat content, carbohydrate content and ash content were tested (Table 2).

Table 1. Mean of Organoleptic Test Values of Meatballs Made from Laying Chicken Afkir

\begin{tabular}{ccc}
\hline Variable & Treatment2) & SE \\
\hline
\end{tabular}




\begin{tabular}{lclllll}
\hline & R0 & \multicolumn{1}{c}{ R1 } & \multicolumn{1}{c}{ R2 } & R3 & R4 & M3) \\
\hline Elasticity (\%) & $5,690 \mathrm{c}$ & $6,173 \mathrm{~b}$ & $6,228 \mathrm{ab}$ & $6,536 \mathrm{a}$ & $6,240 \mathrm{ab}$ & 0.10 \\
Texture (\%) & $5,529 \mathrm{c}$ & $6,484 \mathrm{ab}$ & $6,602 \mathrm{ab}$ & $6,818 \mathrm{a}$ & $6,278 \mathrm{~b}$ & 0.11 \\
Taste (\%) & $6,014 \mathrm{a}$ & $6,647 \mathrm{a}$ & $6,573 \mathrm{a}$ & $6,411 \mathrm{a}$ & $6,127 \mathrm{a}$ & 0.17 \\
Aroma (\%) & $6,424 \mathrm{a}$ & $7,077 \mathrm{a}$ & $6,822 \mathrm{a}$ & $7,222 \mathrm{a}$ & $7,178 \mathrm{a}$ & 0.27 \\
Likes (\%) & $5,808 \mathrm{c}$ & $6,647 \mathrm{a}$ & $6,483 \mathrm{ab}$ & $6,133 \mathrm{bc}$ & $6,044 \mathrm{c}$ & 0.13 \\
Surface & $5,620 \mathrm{a}$ & $6,617 \mathrm{a}$ & $6,622 \mathrm{a}$ & $6,729 \mathrm{a}$ & $6,728 \mathrm{a}$ & 0.27 \\
Smoen
\end{tabular}

Note: Values with the same letter on the same row indicate no significant difference $(\mathrm{P}>0.05)$.

Based on Table 5.1, it can be seen that the chicken meatball with the addition of tapioca flour showed a very significant effect $(\mathrm{P}<0.01)$ on the chewiness, texture, and meatball preferences variables, while there was no significant effect $(\mathrm{P}>0.05)$ on the taste variable. , aroma and surface smoothness.

\subsection{Elasticity}

Based on the organoleptic test results of the elasticity of chicken meatball afkir, the highest value was obtained in the treatment $\mathrm{R} 3$ is 6,536 , which is not significantly different from R2 and R4 with a value of 6.228 and 6.240 respectively. From the research results, it can be seen that more tapioca flour additions increase the elasticity of the meatballs. In the manufacture of meatballs, this tapioca flour functions to improve and stabilize the emulsion, increase the water holding capacity, reduce shrinkage, increase the volume and improve the texture of the meatballs [7]. Tapioca flour which functions as a filler (filler) and a binder (binder). Tapioca contains $86.55 \%$ carbohydrates, the starch consists of two soluble fractions of amylose and an insoluble fraction of amylopectin which causes tapioca to stick when heated [8]. Filler is a non-meat fraction which has the property to bind water and form a gel $[9]$.

\subsection{Texture}

Based on the organoleptic test results of the meatball texture of the abandoned chicken meat, the highest value was obtained in treatment R3, namely 6.818 which was not significantly different from the need for R1 and R2 with values of 6.484 and 6.602 respectively. The texture of the meatballs is influenced by the concentration of tapioca flour added. [10] stated that the formation of gelatinization (gelatinization) of tapioca in the process of making meatballs will produce thickness, density and stiffness, which affect the texture of the meatballs.

\subsection{Taste}

The statistical analysis of the organoleptic test for the taste of chicken meatball with the addition of tapioca flour showed no significant difference. The highest taste value was obtained in treatment R1 with value6,647 which was not significantly different from other treatments. This shows that the addition of tapioca flour does not affect the taste of the meatballs, which still have a distinctive taste of chicken meat.Taste is a sensation that is formed from the combination of ingredients and their composition in a food product by the sense of taste. According to [11] that good quality meatballs have a savory and delicious taste, the dominant taste of the meat and the taste of the seasoning is prominent but not dominant.

\subsection{Aroma}


Based on the research, the organoleptic test of the aroma of chicken meatball with the addition of tapioca flour showed no significant difference. The highest aroma value was obtained in treatment R3 with a value of 7.222 which was not significantly different from other treatments. The distinctive fragrant aroma of chicken meatballs on the chicken meatballs is caused by the fresh chicken used in making the chicken meatballs. Aroma is a distinctive smell that is released from a food which is stimulated through the sense of smell so that it can increase appetite. Aroma can be used as a sign whether or not a food is good. The aroma produced by the food varies, depending on the ingredients and the cooking technique. According to [11], quality meatballs have a distinctive fresh aroma, namely the aroma of fresh meat, not fishy, rotten, rancid, sour, stale,

\subsection{Passions}

Based on statistical analysis, the favorite test of chicken meatball afkir shows a significant difference. The highest favorite value was obtained in R2 treatment with a preference value of 6.647 which was not significantly different from treatment R2 with a preference value of 6.483 . The panelists' preference for the rejected chicken meatballs was influenced by the acceptance of texture, aroma and taste of the meatballs. The lowest favorite value was obtained in the control treatment (R0) with a value of 5.808. This is because the egg-laying hens have a texture that tends to be tough because of the high collagen content and the number of bonds.

\subsection{Surface Smoothness}

The smoothness of the surface of the rejected chicken meatballs showed no significant difference. The highest value of surface smoothness was obtained in treatment R3 with a value of 6.729 which was not significantly different from other treatments. BThe desired shape of the meatball is that when rounding the basko there is no part of the meatball that is still hollow so that it looks smooth on the surface. Meatballs of good quality should have a uniform shape, round, not moldy, not slimy and look shiny [11].

Table 2. Mean of Test Value of the Nutritional Quality of Meatballs Based on Afkir Laying Chicken.

\begin{tabular}{|c|c|c|c|c|c|c|}
\hline \multirow[t]{2}{*}{ Variable } & \multicolumn{5}{|c|}{ Treatment2) } & \multirow{2}{*}{$\begin{array}{c}\text { SEM3 } \\
\text { ) }\end{array}$} \\
\hline & R0 & R1 & $\mathrm{R} 2$ & R3 & R4 & \\
\hline $\begin{array}{l}\text { Protein content } \\
(\%)\end{array}$ & $30,540 \mathrm{a}$ & $18,110 b$ & $16,080 \mathrm{c}$ & $13,220 \mathrm{~d}$ & $11,765 \mathrm{e}$ & 0.25 \\
\hline Fat level $(\%)$ & $2,874 \mathrm{a}$ & $1,876 \mathrm{~b}$ & $1,847 \mathrm{~b}$ & $1,586 \mathrm{~b}$ & $1,560 \mathrm{~b}$ & 0.12 \\
\hline Ash content $(\%)$ & $2,549 \mathrm{a}$ & $1,617 \mathrm{~b}$ & $1,226 \mathrm{~b}$ & $1,453 \mathrm{~b}$ & $1,659 \mathrm{a}$ & 0.19 \\
\hline Water content $(\%)$ & $65.157 \mathrm{~d}$ & $73,665 \mathrm{a}$ & $72,393 \mathrm{ab}$ & $70,846 \mathrm{~b}$ & $69,061 \mathrm{c}$ & 0.52 \\
\hline
\end{tabular}

Note: Values with the same letter on the same row indicate no significant difference (P>0.05).

Based on Table 5.2, it shows that the chicken meatballs with the addition of tapioca flour showed a very significant effect $(\mathrm{P}<0.01)$ on the variables of crude protein content, fat content, ash content and moisture content.

\subsection{Crude Protein Content}

The crude protein content of rejected meat balls with different tapioca starch concentrations showed a very significant difference. The highest protein content was obtained in the control treatment that was $30.540 \%$ and the lowest was in the R4 treatment which was 
$11.765 \%$. The more the addition of tapioca flour decreased the crude protein content of the meatball. This is because the addition of tapioca reduces the amount of chicken meat so that the protein source is reduced. This is in accordance with statement [12], namely that protein content is closely related to the amount and type of chicken meat used and filler fillers. The protein value in this study was higher when compared to research [13] where the substitution of tapioca flour with breadfruit flour ranged from $8.5 \%$.

\subsection{Fat level}

Fat content of chicken meatball finally showed a real difference. The highest fat content was obtained in treatment R0, namely $2.874 \%$. According to SNI, the ideal standard of meatball fat is a maximum of $2 \%$. The addition of tapioca flour reduced the fat content of the refined chicken meatballs. Based on the results of the study, the meatballs with the addition of tapioca flour have fat content that meets the Indonesian national standard, which is below $2 \%$.

\subsection{Ash content}

The ash content of the rejected spinach meatball showed a significant difference. The highest ash content was obtained in treatment R0, namely $2.549 \%$. The ash value in this study was higher when compared to research [14]. The effect of pumpkin porridge (cucurbita moschata) substitution on the quality of chicken meatballs ranged from $1.38 \%$. The value of meatball ash according to SNI is a maximum of $3 \%$, this means that the chicken meatball with the addition of tapioca flour meets the Indonesian national standard 01-3818 of 1995. The ash content of the meat is closely related to the protein content of the meat and the fat-free tissue. [15] stated that a high ash content means that there are quite a number of chemical compounds in the form of salts.

\subsection{Water content}

The water content of the rejected spinach meatballs showed a real difference. The highest water content was obtained in treatment R1, namely $73.665 \%$. The water content of the research results was higher than the study [16] which used tapioca flour, cornstarch and sago flour ranging between $54.67 \%$. According to the Indonesian National Standard, the maximum water content is $70 \%$, which means that R1 and R2 treatments do not meet Indonesian national standards while other treatments meet Indonesian national standards. Water is an important component in food ingredients, because water can affect the texture and taste of food [17]. The water content in food ingredients determines the acceptance and durability of these materials. Most of the changes in food material occur in the water medium added to or originating from the material itself [18].

\section{Conclusion}

Based on the results of the study, the addition of tapioca flour to the manufacture of chicken meatball afkir showed a very significant effect $(\mathrm{P}<0.01)$ on the elasticity, texture, and preferences of the meatballs as well as the variables of crude protein content, fat content, ash content and moisture content. Afkir layer chicken meatballs with the addition of $15 \%$ tapioca flour had the highest value of chewiness, texture and surface smoothness with each value of 6,$536 ; 6,818$ and 6,729 . The treatment of adding $5 \%-20 \%$ tapioca flour fulfilled SNI $01-3818$ of 1995 on parameters of moisture content, ash content, fat content and protein content. 


\section{Acknowledgments.}

The author would like to thank the Chairman of the Yayasan Korpri Propinsi Bali, Rector of Warmadewa University, the Head of the Warmadewa University Research Institute, the Dean of the Faculty of Agriculture and colleagues who have provided all support in completing this research.

\section{References}

[1] F. Ayustaningwarno, "Practical Theory and Application Food Technology". Graha, 2014

[2] S. T. Soekarto, "Organoleptic Assessment for the Food and Agricultural Products Industry". Jakarta: Bharat Karya Aksara, 1985

[3] F. G. Winarno, "Food Chemistry and Nutrition," Jakarta: PT Gramedia Pustaka Utama, 2002

[4] C. Davendra, and M. Burns,. "Goat Production in Tropic," London's Commonwealth Agriculture Bureaux, 1983

[5] Irnawaty, Journal of Animal Science and Industry. volume 3 nomor 1, 2016, 2016

[6] L. M. Maharaja, "Using a mixture of tapioca flour with sago flour and sodium nitrate in making beef meatballs", USU's Faculty of Agriculture. Field, 2008

[7] E. Hasrati, and R, Rusnawati,. "Study of the Use of Carp Meat (Cyprinus Carpio Linn) on the Texture and Taste of Beef Meatballs," Agromedia, volume 29, nomor 1, pp.17-13, 2011

[8] S. Usmiati, "Healthy Meatballs," Agricultural Research and Development Newsletter, volume. 31, 2009

[9] E. S. Widyastuti,. "A Study on the Use of Tapioca, Potato Starch and Modified Starch in Making Beef Meatballs," Universitas Brawijaya Postgraduate Program: Animal Science Thesis Study Program, 1999

[10]R. Sunarlim, "The Role of $\mathrm{NaCl}$ on Meatball Quality". Presented at the National Seminar on the Role of Animal Husbandry in the Development of Underdeveloped Villages. Semarang, 1994

[11]B. Sutomo, "Bakso". Jakarta Business Success: Craft Pustaka, 2013

[12]R. Mastuti, "Effect of temperature and length of frying time on the physical and chemical quality of restructured mutton," Journal of Animal Product Science and Technology volume 3, nomor 2, pp. 23-31, 2008

[13] A. S. Prastya, D. Rosyidi, and Imam, "Substitution of tapioca flour with breadfruit flour on $\mathrm{pH}$, moisture content, protein content, hardness, and cooking losses of beef meatballs," Malang: Brawijaya University, 2013

[14] V. Herwin, T. H. Manurung, D. J. Tuju, L. C. Mandey, and M. M. Ludong, "Effect of pumpkin porridge (cucurbita moschata) substitution on the quality of chicken meatballs". Manado: Faculty of Agriculture, Sam Ratulangi University, 2014 
[15] S. Komansilan, and S. Sakul, "The Effect of the Use of Several Types of Fillers on the Chemical Properties of Afkir Chicken Nuggets," Zootec, volume 38, nomor 2, pp. $357-367,2018$

[16]H. Rahmawaty, and W. Ma'aruf,. "Samratulangi University Animal Husbandry University. Manado," Zootek Journal, volume 23, pp. 114-119, 2006

[17]E. Persson, I. Sjokolm, and K. Skog.. "Effect of high water-holding capacity on the formation of heterocyclic amines in fried beefburgers," Journal of Agriculture Food Chemistry, volume 51, nomor 15, pp. 4472- 4477, 2003

[18]D. Fardiaz, N. Andarwulan, H. Wijaya, and N. L. Puspitasari, "Techniques for Analysis of Chemical and Functional Properties of Food Components (Laboratory Guidelines) ". Depdikbud Dirjen Dikti. PAU for Food and Nutrition, 1992 